4 pages only and the Retina 10 pages but both are models of succinct writing. The final chapter on The Tears and the Lids is especially useful with some new information on the eyelid during blinking.

Professor Fatt indicates in his preface that he has deliberately omitted the electrophysiology of the optic nerve, retina and extra-ocular muscles. This is understandable in the interests of brevity but probably the book could achieve a much wider readership if these were included in any future editions. A most excellent and readable little book which will be obligatory reading for optometric students, those embarking on ocular physiology research and any member of one of the health professions requiring a good introduction to the physiology of the eye.

\section{Recent Advances in Gastroenterology}

Edited by Ian A. D. Bouchier. Pp. viii +338 , hard cover, illustrated. Churchill Livingstone, Edinburgh, 1976.

This is number 3 in the ever popular Recent Advances in Gastroenterology series, with chapters by 18 authors, 9 from the U.K., 3 Canadians and 6 from the U.S.A. Progress in gastroenterology has been so rapid that the editor, Professor Bouchier faces a self-confessed unenviably difficult choice. Quite rightly, paediatric gastroenterology claims 2 chapters on liver disease in infants and children and on cystic fibrosis of the pancreas. The use and abuse of laxatives is dealt with authoritatively, references dated up to 1975 documenting continuing developments in this area. Hormonesecreting tumours of the gut, effects of small bowel resection, and of alcohol on the gut, endoscopic cannulation of the papilla of Vater, bile acid metabolism and shunts for hepatic disease are among the other topics covered. There are good reviews of fat absorption. The chapter on hiatus hernia and the gastro-oesophageal junction is disappointing, not because the review of the literature is incomplete, but because of absence of any critical evaluation of the various studies cited and of their relevance to clinical practice. Review of the connective tissue disorders that affect the gut provides a link with general medicine and a useful reminder of some of the rarer diagnoses. The book is produced and illustrated to a high standard. It is to be highly recommended, both for libraries and for personal bookshelves of general physicians and gastroenterologists. The Editor can be congratulated on an expert job of work and on his iconoclastic omissions of the sacred cows of fibre, therapy of peptic ulcer and medical treatment of gall stones.

Sexual Endocrinology. Hormone Relations and the Physiopathology of Pregnancy. Hormone Investigations. Hypothalamic-Hypophyseal Relations

Edited by R. Vokaer and R. De Mauberge. Pp. viii +272 , illustrated. Masson Publishing: New York, Paris, Barcelona and Milan. Abacus Press, Tunbridge Wells, 1978. $£ 26.35$.

Most people agree that too many medical and para-medical books are published. Sexual Endocrinology edited by Vokaer and Mauberge is one of the too many. It consists of 17 chapters on a variety of subjects in the general field of reproductive endocrinology. They vary from $1 \frac{1}{2}$ to 30 pages in length and mainly contain information that has been published elsewhere, not only in the form of original scientific articles but also within widely available reviews, often by the same authors. The book costs $£ 26.35$. I do not recommend you to buy it.

\section{Soft Contact Lenses. Clinical and Applied Technology}

Edited by Montague Ruben. Pp. xiii +496 , illustrated. Baillière Tindall, London, 1978. £21.00.

The size of this book, almost 500 pages, is an indication of the enormous interest and advances made specifically in soft contact lenses since their introduction into clinical practice during 1961. Montague Ruben, an expert in the field of contact lenses in general, is the editor of this beautifully produced book. There are 28 contributors each one concentrating on an aspect of the soft contact lens with which he has particular experience. The editor rightly states this is not a book for the beginner but even those with a rudimentary knowledge of soft contact lenses would find the book fascinating reading. For the expert in the clinical use of soft lenses there is much to be gained from the sections dealing with technology and applied science. For the researcher there is much to be learned from the clinical practical sections.

The book has 5 sections, each one dealing with a special aspect of the soft contact lens, commencing with the Historical Development and continuing through Applied Sciences, Clinical Practice, Pathology, Toxicology and Pharmacology, and finally the Technology of Manufacture. The editor himself contributes to the sections on Clinical Practice and Pathology. An international flavour to the book is apparent, not only from the styles of writing but from the fact that 10 different countries are represented amongst the 28 contributors. Printed in clear type on quality paper there are liberal, beautifully reproduced illustrations. The size, definition and quality of most of the tables and diagrams is a model for others to follow. There is a centre insert of 18 pages of excellent colour photographs relating to different sections in the book. As always, it is a minor irritation not having these colour illustrations with the text but the increase in cost involved presumably gives rise to this arrangement.

The editor and contributors are to be congratulated on a first class book which will remain essential reading for all those involved in the clinical practice of soft contact lenses for years to come. A comprehensive book of this nature has been much needed. Researchers will find much basic and advanced information not easily obtained in such a readable form with copious references. At $£ 21.00$ this book may seem a little expensive but for the content and quality it must be considered good value, and is highly recommended.

\section{The Wheelchair Child}

By Philippa Russell. Human Horizons Series. Pp. 388 , illustrated. Souvenir Press Ltd, London, 1978. £6.00.

This is an important book for physiotherapists, occupational therapists, doctors and surgeons dealing with the handicapped child.

There are many interesting thoughts on mobility aids for the disabled, and these also include other related walking frames, chariots and similar appliances. Physiotherapy, play therapy and other treatments of the disabled person using this apparatus are also well covered.

At the modest price of $£ 6$ it is highly recommended for all those dealing with the handicapped child. 